\section{Trees for the Southern Great Plains}

\author{
Lynn Ellen Doxon' and \\ Rex Kirksey ${ }^{2}$
}

Additional index words. Chilopsis

linearis, Gymnocladus dioica, Juniperus ashei, Juniperus chinensis pfitzeriana, Juniperus monosperma, Juniperus pachyphlaea, Juniperus pinchotii, Juniperus virginiana, Pinus edulis, Pistacia chinensis, Thuja orientalis, Ziziphus jujuba

Summary. Between 1923 and 1987, several tree species were tested for long-term survival under dryland conditions at the New Mexico State Univ. Agricultural Science Center at Tucumcari. Of those tested, three deciduous species-Chilopsis linearis, Ziziphus jujuba, and Gymnocladus dioica- had a survival rate $>50 \%$. Among the evergreen species, Thuja orientalis varieties Goldspire, Gracillis, Berkman, Baker, and Excelsa had good survival rates, as did Juniperus ashei, J. chinensis pfitzeriana, J. pachyphlaea, J. pichottii, J. monosperma and $J$. virgiana. These species and varieties can be used successfully in dryland plantings in the Western Great Plains once established.

$\mathrm{F}$ or more than 100 years, residents of the Western Great Plains have been planting trees and shrubs to improve living conditions and protect property from climatic extremes. Early settlers dug seedlings from streambanks for planting around their homesteads. Later, species were imported from other areas. Many of these species were not adapted to their new environment and did not survive. In 1923, studies were begun at Tucumcari, N.M., on the long-term

New Mexico State University, Las Cruces, NM 88003. ${ }^{\prime}$ Extension Horticulture Specialist, Extension Plant Science Dept.

${ }^{2}$ Superintendent, Agricultural Science Center at Tucumcari.

The cost of publishing this paper was defrayed in part by the payment of page charges. Under postal regulations, this paper therefore must hereby be marked advertisement solely to indicate this fact. survival of certain tree species (Read, 1964). Large-scale tree plantings were made in 1923, 1931, and 1938. The recommendations in this article are based on survival of those trees until 1987. Average annual precipitation in the area is 15.66 inches $(39.8 \mathrm{~cm})$. During the years of the study, precipitation ranged from 6.13 inches (15.6 $\mathrm{cm})$ in 1934 to 34.96 inches $(88.8 \mathrm{~cm})$ in 1941. Tucumcari is in USDA plant hardiness zone 6B. Temperatures during the study ranged from a high of $108 \mathrm{~F}$ (42C) in 1939 and 1957 to a record low of $-22 \mathrm{~F}(-30 \mathrm{C})$ in 1963. Average length of the growing season is 188 days, with a range from 136 days to 217 days during the study (Kirksey, 1987).

\section{Recommended deciduous species}

Only three deciduous species had good survival rates over the 64 years of the study. These were Chilopsis linearis, Ziziphus jujuba, and Gymnocladus dioica. These trees can be considered for landscaping, windbreak, and livestock shelter plantings. Chilopsis linearisis a small, flowering tree related to the catalpa. Flower colors range from white through pink to shades of purple. The flowers are present all summer and attract hummingbirds, making it a desirable addition to the landscape. Ziziphus jujuba is a medium-size tree that has glossy green leaves and produces an edible fruit that tastes like a date when it is ripe. It is a thorny tree, and formed a thicket under the conditions of the study. Suckering needs to be controlled, and dropped fruit requires cleaning up in the landscape. It fails to produce fruit in dry years. The average height was $14 \mathrm{ft}(4.2 \mathrm{~m})$ under the conditions of this study. Gymnocladus dioica is normally a large tree that produces a bean-like seedpod. Its height was limited to an average of only $10 \mathrm{ft}(3 \mathrm{~m})$ by the conditions of this study. It would benefit from supplemental irrigation in dry years if it were planted as a specimen plant. By 1987, both Gymnocladus dioica and Chilopsis linearis had more than one-third dead wood. This was after 50 to 65 years without pruning. Since 1949 , the trees had received no maintenance at all. In a landscape situation, regular appropriate pruning would be necessary.

Other deciduous species survived for the first 25 years of the study, but were not alive in 1987. These included
Catalpa speciosa, Celtis occidentalis, Fraxinus pennsylvanica, Fraxinus velutina glabra, Gleditsia triacanthos, Hibiscus syriacus Malus spp., Melia azedarach, Prunus armeniaca, Prunus cistena, Prunus angustifolia watsonii, Prunus costena, Tamarix hispida, Tamarix odessana, Tilia americana, Ulmus americana, and Ulmus Davidiana japonica (Burnham, 1922-1950). These species can be used where shortterm plantings are needed or where irrigation is available, but should not be considered for long-term use without irrigation. They would be good choices where limited supplemental irrigation could be provided. Weak wood and fruit drop pose problems in the landscape use of some of these species.

Only two Pistacia chinensis trees were planted, and both survived for the duration of the study. Although data are too limited to support a recommendation, the Pistacia chinensis may be another good choice for dryland situations on the Southern Great Plains. The two surviving trees were among the most-attractive deciduous trees in the study. Pistachia chinensis has a rather gangly form when young, but it grows to be a neat, round-crowned tree, resembling an ash with age. Scarlet to crimson fall color is its most spectacular asset. Some individuals also appear to be resistant to mistletoe.

\section{Recommended evergreen species}

Several varieties of juniper and oriental arborvitae had high survival rates. Two Thuja orientalis varieties, Goldspire and Gracillis, had 100\% survival rates with no dead wood visible in 1987. 'Berkman' arborvitae had a $90 \%$ survival rate, and both 'Baker' and 'Excelsa' had survival rates $>70 \%$. All of these are compact varieties. All except 'Gracillis' averaged $\approx<10 \mathrm{ft}(3 \mathrm{~m})$ tall and wide under dryland conditions. 'Gracillis' averaged almost $14 \mathrm{ft}$ $(4.2 \mathrm{~m})$ tall and just more than $7 \mathrm{ft}$ (2.2 $\mathrm{m})$ wide. An unnamed oriental arborvitae had a survival rate of $51 \%$ and was almost $18 \mathrm{ft}(5.4 \mathrm{~m})$ tall. Large types, such as the unnamed entry, would be best for windbreak plantings. In landscape situations, it should be remembered that even the compact varieties can grow to be $10 \mathrm{ft}(3 \mathrm{~m})$ wide and/ or $10 \mathrm{ft}(3 \mathrm{~m})$ tall over time-adequate space should be allowed in the landscape.

Juniperus ashei, Juniperus pachy- 
Table 1. Survival, height, crown width, and dead wood estimate for tree and sbrub plantings near Tucumcari, N.M., 1987.

\begin{tabular}{|c|c|c|c|c|c|c|}
\hline \multirow[b]{3}{*}{ Scientific and common names } & \multicolumn{2}{|c|}{ No. of } & \multirow{3}{*}{$\begin{array}{l}\text { Survival over } \\
65 \text { years }(\%) \\
\end{array}$} & \multirow{2}{*}{\multicolumn{2}{|c|}{ Average }} & \multirow{3}{*}{$\begin{array}{c}\text { Estimated dead } \\
\operatorname{wood}(\%)\end{array}$} \\
\hline & \multirow{2}{*}{$\begin{array}{l}\text { Plantings } \\
(1923-38)\end{array}$} & \multirow[b]{2}{*}{ Trees } & & & & \\
\hline & & & & Height (m) & Crown width (m) & \\
\hline Caragana arborescens (Siberian pea shrub) & 1 & 48 & 56 & 1.0 & 1.3 & 5 \\
\hline Carya illinoensis (Pecan) & 5 & 23 & 9 & 2.6 & 2.1 & 12 \\
\hline Cercis canadensis (Eastern redbud) & 2 & 13 & 23 & 0.4 & 1.3 & 0 \\
\hline Cbilopsis linearis (Desert willow) & 2 & 55 & 100 & 2.6 & 2.8 & 38 \\
\hline Continus coggygria (American smoketree) & 3 & 18 & 6 & 3.3 & 3.1 & 5 \\
\hline Cupressus arizonica (Arizona cypress) & 3 & 22 & 32 & 6.4 & 5.1 & 28 \\
\hline Fraxinus americana (White ash) & 2 & 10 & 10 & 4.4 & 3.3 & 95 \\
\hline Gymnocladus dioica (Kentucky coffee tree) & 2 & 6 & 83 & 3.0 & 3.1 & 42 \\
\hline Juglans nigra (Black walnut) & 7 & 28 & 4 & 3.5 & 2.5 & 90 \\
\hline Juniperus ashei (Ozark white cedar) & 1 & 5 & 100 & 4.0 & 4.9 & 0 \\
\hline Juniperus chinensis pfitzeriana (Pfitzer) & 3 & 15 & 73 & 1.2 & 3.7 & 15 \\
\hline Juniperus horizontalis (Creeping juniper) & 2 & 12 & 17 & 1.3 & 6.2 & 0 \\
\hline Juniperus monosperma (Single seed juniper) & 2 & 18 & 50 & 4.0 & 5.0 & $\mathrm{I}$ \\
\hline Juniperus pachyphlaea (Alligator juniper) & 1 & 5 & 100 & 4.1 & 5.2 & 2 \\
\hline Juniperus pinchotii (Red juniper) & 1 & 5 & 100 & 3.9 & 4.9 & 0 \\
\hline Juniperus sabina (Savin juniper) & 1 & 10 & 10 & 0.6 & 0.5 & 0 \\
\hline Juniperus scopulorum (Rocky Mountain juniper) & 5 & 65 & 17 & 4.1 & 4.4 & 20 \\
\hline Juniperus virginiana (Eastern redcedar) & 10 & 126 & 41 & 4.1 & 4.9 & 8 \\
\hline Morus alba tatarica (White mulberry) & 4 & 267 & 13 & 2.7 & 2.4 & 53 \\
\hline Morus rubra (Red mulberry) & 5 & 119 & 5 & 2.6 & 2.4 & 59 \\
\hline Pinus edulis (Piñon pine) & 5 & 142 & 19 & 6.0 & 4.3 & 4 \\
\hline Pinus ponderosa (Ponderosa pine) & 8 & 222 & 3 & 3.1 & 2.8 & 8 \\
\hline Prunus persica (Peach) & 1 & 10 & 20 & 4.2 & 7.1 & 42 \\
\hline Tamarix amurensis (Tamarisk) & 1 & 20 & 15 & 2.1 & 2.0 & 83 \\
\hline Thuja orientalis (Oriental arborvitae) & 6 & 219 & 51 & 5.4 & 3.8 & 0 \\
\hline Thuja orientalis 'Baker' (Oriental arborvitae) & 4 & 20 & 70 & 2.9 & 1.6 & 0 \\
\hline Thuja orientalis 'Berkman' (Oriental arborvitae) & 2 & 29 & 93 & 2.8 & 2.1 & 0 \\
\hline Thuja orientalis 'Excelsa' (Oriental arborvitae) & 2 & 17 & 71 & 2.3 & 1.4 & 0 \\
\hline Thuja orientalis 'Goldspire' (Oriental arborvitae) & 1 & 10 & 100 & 2.8 & 2.9 & 0 \\
\hline Thuja orientalis 'Gracillis' (Oricntal arborvitac) & 1 & 5 & 100 & 4.2 & 2.2 & 0 \\
\hline Ulmus pumila (Siberian elm) & 6 & 413 & 2 & 3.6 & 3.4 & 11 \\
\hline Ziziphus jujuba (Jujube) & 4 & 33 & 79 & 4.2 & 3.0 & 21 \\
\hline
\end{tabular}

phlaea, and Juniperus pinchotii all had survival rates of $100 \%$. Juniperus monosperma had only a 50\% survival rate, but all deaths occurred in the first year after planting. Thus, it appears that Juniperus monosperma may be more difficult to establish, but it has a longterm survival rate equal to the other hardy junipers. Juniperus virginiana was also difficult to establish; it had an $84 \%$ survival rate after establishment. All of these junipers could be used either as windbreak or landscape trees. Juniperus pachyphlaea has interesting scaly bark. Juniperus pinchottii has a reddish-brown fruit, rather than the more-familiar greenish blue. These are all upright, tree-like junipers and have a somewhat gnarled appearance under dryland conditions.

Of the shrub-type junipers tested, only the pfitzeriana ('Pfitzer') had a high survival rate. 'Pfitzer' was the only variety of Juniperus chinensis tested. One Juniperus sabina variety was tested and had very low survival rates. Juniperus horizontalis douglasii had a survival rate $60 \%$ in the first 4 to 20 years of the study, but none were alive in 1987. It may be appropriate for short-term use. Since the time ofplanting for these trials, many juniper varieties have been developed. The 'Pfitzer', because of its mature size, is not now considered among the best choices for typical landscape situations. Some of the newer, smaller varieties of Juniperus chinensis might be considered for home landscaping.

Pinus edulis had low survival rates for the first 2 years, but $75 \%$ of those that survived the establishment period were still alive at the end of the study. Those that survived had an average height of 19 $\mathrm{ft}(6 \mathrm{~m})$ and only $4 \%$ dead wood.

\section{Unsuccessful trees}

Eight species of trees were tested, but began to die soon after planting. Each species was planted at least three different times, and most plants of the species were dead within 8 years of planting. They included Juniperus communis suecica, Picea glaucu, Picea pungens, Pinus banksiana, Pinus nigra, Pinus sylvestris, Platanus occidentalis, and Shepherdia agentea. These species are not adapted to the dryland conditions of this study.

Other trees that survived until 1987 , but at rates $<50 \%$, are listed in Table 1.

\section{Literature Cited}

Burnham, D.R. 1922-1950. Annual progress reports. Tucumcari Field Station, Bureau of Plant Industry, USDA.

Kirksey, R.E. 1987. Weather observations at the Agricultural Science Center at Tucumcari, 1905-1985. New Mexico Agricultural Experiment Station. Res. Rpt. 621.

Read, R.A. 1964. Tree windbreaks for the Central Great Plains. Forest Serv., USDA. Agr. Hdbk. 250. 